\title{
Atmospheric air quality after pollutant emission in urban area of the municipality of Lages/SC
}

The atmospheric air pollution started to become a public health issue in the Industrial Revolution, when the current urbanization system was defined. Chemical species emitted via anthropological activities are capable of acting on people, animals and plants, making air pollution one of the greatest problems in urban areas today. In this sense, the present study aimed to quantify the emissions of $\mathrm{CO}, \mathrm{CH} 4$, NO, NO2 and SO2 in urban area of the municipality of Lages/SC, comparing their concentrations with control points located in an Environmental Protection Unit. It was verified if the concentrations of $\mathrm{CO}$, NO2 and SO2 are in accordance with the air quality standards, as well as their respective levels (attention, alert or emergency level), as established by the CONAMA Resolution $\mathrm{n}$. 491/2018. The air quality rate was compared with values determined by the CETESB air quality index. All samples were collected and analyzed (at four replicates) using portable measuring instruments. The meteorological influences on the studied pollutants were evaluated in both control and urban areas. The NO2 levels in the study atmospheric air exceeded the values of the quality standard, being considered as very bad air. Overall, there are potential risks for people breathing this type of atmospheric air.

Keywords: Air quality; Atmospheric pollution; Urban area; Gaseous pollutant.

\section{Avaliação da qualidade do ar a partir de emissões atmosféricas na área urbana do município de Lages/SC}

\begin{abstract}
Os efeitos provenientes da poluição atmosférica passaram a ser considerados uma questão de saúde pública a partir da Revolução Industrial, quando o sistema de urbanização atual teve origem. As substâncias emitidas pelas atividades antrópicas são capazes de atuar sobre o homem, os animais e as plantas, tornando a poluição atmosférica um dos mais graves problemas das áreas urbanas na atualidade. Nesse sentido, objetivou-se com o presente estudo quantificar as emissões de $\mathrm{CO}, \mathrm{CH} 4, \mathrm{NO}, \mathrm{NO} 2$ e SO2, na área urbana do município de Lages-SC, comparando-as com concentrações obtidas em pontos de controle, localizados em uma Unidade de Conservação de Proteção Integral em Lages. Por fim, verificar se os níveis de CO, NO2 e SO2 estão de acordo com os padrões finais de qualidade do ar, e determinar nível de atenção alerta ou emergência, conforme disposto pela Resolução CONAMA no 491/18, e ainda classificar a qualidade do ar de acordo com o Índice de Qualidade do Ar da CETESB. A amostragem foi realizada com equipamentos de medição portáteis e de resultados instantâneos, em quatro repetições, das 08:00 e 19:00h entre os meses de fevereiro de março de 2020. Constatou-se a influência de elementos meteorológicos sobre o comportamento dos poluentes, tanto na área controle como na área urbana, e que os níveis de NO2 presentes na atmosfera excederam o Padrão Final de qualidade do ar, classificando-o como muito ruim, e estabelecendo nível de atenção para os danos à saúde da população.
\end{abstract}

Palavras-chave: Qualidade do ar; Poluição atmosférica; Área urbana; Poluente gasoso.

Topic: Planejamento, Gestão e Políticas Públicas Ambientais

Reviewed anonymously in the process of blind peer
Received: 06/07/2021

Approved: $27 / 07 / 2021$
Jordana dos Anjos Xavier (iD)

Universidade do Estado de Santa Catarina, Brasil

http://lattes.cnpq.br/1562975042294996

http://orcid.org/0000-0002-1674-9812

jordanaxavier94@gmail.com

Valter Antonio Becegato (D)

Universidade do Estado de Santa Catarina, Brasil

http://lattes.cnpq.br/3196823526572670

http://orcid.org/0000-0002-6850-2846

valter.becegato@udesc.br

Débora Cristina Correia Cardoso

Universidade do Estado de Santa Catarina, Brasil

http://lattes.cnpq.br/2767570871721905

deboracccardodo@hotmail.com
Vitor Rodolfo Becegato (iD

Universidade do Estado de Santa Catarina, Brasi

http://lattes.cnpq.br/7642634231071974

http://orcid.org/0000-0003-4177-5833

vitorvrb92@gmail.com

Alexandre Tadeu Paulino (i)

Universidade do Estado de Santa Catarina, Brasil

http://lattes.cnpq.br/8957379372810063

http://orcid.org/0000-0001-7076-2797

alexandre.paulino@udesc.br
Referencing this:

XAVIER, J. A.; BECEGATO, V. A.; CARDOSO, D. C. C.; BECEGATO, V. R.; PAULINO, A. T.. Atmospheric air quality after pollutant emission in urban area of the municipality of Lages/SC. Revista Ibero Americana de Ciências Ambientais, v.12, n.7, p.511-521, 2021. DOI: http://doi.org/10.6008/CBPC2179-6858.2021.007.0044 


\section{INTRODUCTION}

The atmospheric air pollution with either inorganic or organic pollutants started when the human being discovered fire (BAKONYI et al., 2004). The first pollution signals appeared after burns in areas used for planting. Nowadays, this problem is much more serious in urban areas. The atmospheric air pollution indices became a public health issue from the industrial revolution between the $18^{\text {th }}$ and $19^{\text {th }}$ centuries, when the currently known urbanization system was defined. Many anthropological activities in big cities contribute for the atmospheric air pollution, including the use of vehicles and the industrial operations (BRANCO et al., 2010). Gaseous pollutant species released in the atmosphere from different anthropological sources cause serious health problems for human beings, animals and plants (FELLENBERG, 1980).

According to Ebi et al. (2008), the pollutant concentration in the atmospheric air depends on climate, wind, anthropological activities, and so forth. There are stationary and mobile atmosphere air pollution sources (Paraná Environmental Institute, 2020. Stationary sources are thermoelectric power plants, waste incinerators and natural sources such as salt air and volcanism; but the most significant ones, with the biggest pollution potential are industries. Mobile sources are motor vehicles, including trains, ships and airplanes; however, in urban areas, vehicles are considered the main polluting sources (IAP, 2020).

Meteorological conditions cause significant impacts on the behavior of atmospheric pollutants, as well as in their dilution, diffusion, distribution and concentration in the environment (QI et al., 2021). Thus, there are places that are prone to bad air quality due to their topography and climate, since climate can favor chemical reactions, transforming the emissions. Moreover, topography restricts the dispersion of pollutants (EBI et al., 2008). Overall, the air quality is influenced by the climate conditions of each region. It can be evaluated from two variables: climate conditions and emission rate of pollutants (TONG et al., 2018; WOLF et al., 2014). Grange et al. (2019) affirm that is difficult to indicate if certain concentrations of pollutants in the atmosphere are due to local climatic conditions or factors related to emission source.

As well as damages caused to health and wellness of the population, alterations in the quality of soil, water and air bring financial losses for the administration of a State due to the increase in the disease rates, hospital internments and use of medications. It could be avoided or reduced with air quality improvements (BRAZIL, 2020). The effects of the bad air quality on the human health have been evaluated in epidemiologic studies all around the world, since there are evidences that the exposure to atmospheric pollution is associated to the growing number of mortality and morbidity, specially by respiratory and cardiovascular diseases, as well as other health issues such as cancer, congenital malformations and fertility disorders (FREITAS et al., 2013; MARCO et al., 2019).

Bayat et al. (2019) point out that the effects caused by the atmospheric pollution increase the economic and social costs, since the occurrence of morbidities and deaths lead to loss of works. With this, governments face the challenge of controlling the air quality and allocate resources to improve quality of life of the inhabitants through investments in public transport, traffic management and fuel quality, and incentives to alternative means of transportation (BAYAT et al., 2019). 
Urban air management is a way to understand and describe how local authorities deal with the air pollution in urban areas, how they are capable of converting available data in public policies, and is based on the comprehension of problems and their possible solutions to bad air quality. However, evidences are needed in order to prioritize and direct actions according to each flaw identified, as well as to point out opportunities that link atmospheric pollution management to broader actions (BRUNT et al., 2016; FRANCO et al., 2019). Thus, knowledge the air quality supports decisions regarding measures of mitigation and control of the atmospheric pollution. The identification and quantification of pollutant species require a continuous monitoring of the composition of the breathed air (BRANCO et al., 2010). Air quality monitoring provides the verification of compliance to the legally established standards since, from the available data, it is possible to determine critical situations needing emergency plans, as well as identifying evolution trends in the concentrations of pollutants and evaluate the impacts generated by emitting sources (FRONDIZI, 2008).

In this work we aimed to quantify the emissions of carbon monoxide (CO), methane $\left(\mathrm{CH}_{4}\right)$, nitrogen monoxide (NO), nitrogen dioxide $\left(\mathrm{NO}_{2}\right)$ and sulfur dioxide $\left(\mathrm{SO}_{2}\right)$ in the urban area of the municipality of Lages$\mathrm{SC}$, comparing their concentrations to the values in control points located in an environmental conservation unit in the Lages city, and check if the levels of $\mathrm{CO}, \mathrm{NO}_{2}$ and $\mathrm{SO}_{2}$ are in accordance with the legal standards.

\section{METHODOLOGY}

\section{Study Area}

The municipality of Lages-SC is located in the highlands of the state of Santa catarina, being the largest of the state in terms of territory, having 157,544 inhabitants, with $97.11 \%$ of them living in urban areas and only $2.89 \%$ in rural areas. Its economy is based on the following eight sectors, established in function of their respective importance regarding the number of companies and jobs: agriculture, livestock and forest production, the manufacturing of food, beverages, wood products, cellulose pulp, paper and its derived products, machinery and equipments, as well as logistics and retail business (NASCIMENTO et al., 2017).

According to the Köppen-Geiger climate classification, Lages has a temperate climate with mild summers (KOTTEK et al., 2006). During winter there is the occurence of frost and even snowfalls, since climate conditions are influenced by continental antarctic air masses (MONTEIRO, 2001). Mean maximum and minimum monthly temperatures are $28^{\circ} \mathrm{C}$ and $10.8^{\circ} \mathrm{C}$ respectively (SANTA CATARINA, 1986), with rainfalls relatively well distributed during the year (SOCCOL et al., 2010).

\section{Control Points}

The control points were utilized as references of air quality, since an absence of emitting sources in the urban area of the town, since these are located in an Integral Protection Conservation Unit within the municipality. This conservation unit is named João José Theodoro da Costa Neto Natural City Park (PARNAMUL), with the presence of Araucária Moist Forests, part of the Atlantic Forest biome. The 
PARNAMUL has an area of $2.34 \mathrm{~km}^{2}$, with fragments of the original Atlantic Forest vegetal cover, as well as a great diversity of fauna and flora species, with endangered species among them.

\section{Urban Area Sampling Points}

The sampling points were determined in a way that would cover significant areas of the city regarding people flow, industrial presence, as well as flow of vehicles and its type. The locations of all twenty sampling points are shown in Figure 1.

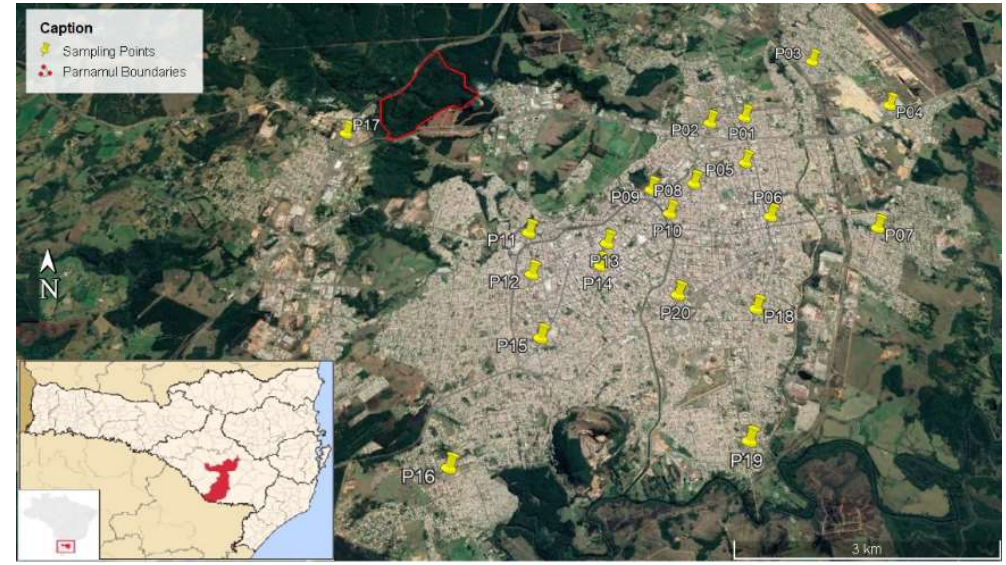

Figure 1: Locations of the sampling points within the urban area of Lages, Santa Catarina. Source: Adapted from Google Earth Pro (2019).

\section{Sampling}

Sampling was conducted for 30 days during the months of February and March. The sampling days had an absence of rainfall and presence of mild winds. Since there are no technical standards regarding the measurement of the levels of atmospheric pollutants with portable equipment, the measurements in this study were performed based on the procedures established by the Brazilian Association of Technical Standards (ABNT) Norm n.10,051:2019 for evaluation of noise, since it makes reference to the use of a portable instrument similar to those utilized in the present study to measure the levels of atmospheric pollutants. Therefore, the instrument was at, approximately, $1 \mathrm{~m}$ above ground level.

Each sampling lasted for approximately 30 minutes in each point. Four samplings were conducted in all twenty points, with each procedure being performed within the same day, between 8:00 AM and 7:00 PM, changing the order of collection in each sampling to ensure that the procedures could be run in different times of the day. The data were instantly obtained, with the information being collected every ten minutes in each point, with 3 measurements per point.

The levels of the following pollutants were measured: $\mathrm{CO}, \mathrm{CH}_{4}, \mathrm{NO}, \mathrm{NO}_{2}$ and $\mathrm{SO}_{2}$. The instruments utilized were: MiniRAE 3000: A Volatile Organic Compound (VOC) analyzer, equipped with a photoionization detector (PID), with a $10.6 \mathrm{eV}$ gas-discharge lamp. The gases measured were $\mathrm{NO}$ and $\mathrm{NO}_{2}$; Eagle Series Portable Multi-Gas Detector: detects gases based on catalystic combustion, eletrochemical cell, galvanic cell and infrared. It is a portable device capable of measuring hydrocarbons $\left(\mathrm{CH}_{4}\right.$ as standard), oxygen $\left(\mathrm{O}_{2}\right), \mathrm{CO}$ and $\mathrm{H}_{2} \mathrm{~S}$; GasAlert Extreme Single-Gas Detector: a portable device that measures $\mathrm{SO}_{2}$ concentrations with an 
electrochemical cell as a plug-in measuring sensor. It has a measuring range between 0 and 100 ppm; operating temperature and humidity are, respectively, between -40 to $50^{\circ} \mathrm{C}$ and 15 to $90 \%$.

Besides the measurements of gas levels, temperature, air humidity and wind speed data were retrieved from the Agribusiness Research and Rural Extension Company of Santa Catarina (EPAGRI) database, according to the date and time of each sampling.

\section{Data Analysis}

For conforming to the legislation, a comparison between the concentrations of $\mathrm{SO}_{2}, \mathrm{NO}_{2}$ and $\mathrm{CO}$ with the maximum allowed values of the Final Air Quality Standard (PF) established by the Conama Resolution n.491/18, based on the 2005 WHO definitions, which are shown in Table 1 (BRAZIL, 2018).

Table 1: Concentrations of Atmospheric Pollutants according to the CONAMA Resolution n.491/18.

\begin{tabular}{l|l|l}
\hline Atmospheric Pollutant & Final Standard (FS) & 20 \\
\hline \multirow{2}{*}{ Sulfur Dioxide $-\mathrm{SO}_{2}\left(\mu \mathrm{g} / \mathrm{m}^{3}\right)$} & 24 hours & - \\
\cline { 2 - 3 } & Yearly & 200 \\
\hline \multirow{2}{*}{ Nitrogen Dioxide $-\mathrm{NO}_{2}\left(\mu \mathrm{g} / \mathrm{m}^{3}\right)$} & Hourly & 40 \\
\cline { 2 - 3 } & Yearly & 9 \\
\hline Carbon Monoxide - $\mathrm{CO}(\mathrm{ppm})$ & 8 hours & \multicolumn{2}{|l}{} \\
\hline
\end{tabular}

Source: Adapted from Brazil (2018).

In order to classify air quality in Lages, the mean value obtained was evaluated according to the Air Quality Index, present in the Environmental Company of the State of São Paulo (CETESB), according to the Table 2 below (CETESB, 2019).

Table 2: Air Quality Classification based on the Air Quality Index.

\begin{tabular}{l|l|l|l|l}
\hline Air Quality Index & Rating & CO $\mathbf{8 h}(\mathbf{p p m})$ & $\mathbf{N O}_{\mathbf{2}} \mathbf{2 4 h}\left(\boldsymbol{\mu g} / \mathbf{m}^{\mathbf{3}}\right)$ & $\mathbf{S O}_{2}\left(\boldsymbol{\mu g} / \mathbf{m}^{\mathbf{3}}\right)$ \\
\hline $\mathbf{0 - 4 0}$ & Good & $0-9$ & $0-100$ & $0-20$ \\
\hline $\mathbf{4 1 - 8 0}$ & Moderate & $>9-11$ & $>100-320$ & $>20-40$ \\
\hline $\mathbf{8 1 - 1 2 0}$ & Bad & $>11-13$ & $>320-1130$ & $>40-365$ \\
\hline $\mathbf{1 2 1}-\mathbf{2 0 0}$ & Awful & $>13-15$ & $>1130-2260$ & $>365-800$ \\
\hline $\mathbf{2 0 0}$ & Poor & $>15$ & $>2260-3000$ & $>800$ \\
\hline
\end{tabular}

Source: Adapted from CETESB (2019).

Levels of attention, warning and emergency were determined for the mentioned pollutants, which indicate acute episodes of air pollution, also based on the standards contained in the Conama Resolution n.491/18, according to the Table 3 (BRAZIL, 2018).

Table 3: Attention, Warning and Emergency levels for pollutants.

\begin{tabular}{l|l|l|l}
\hline \multirow{2}{*}{ Levels } & Pollutants and Concentrations & $\begin{array}{l}\text { CO } \mathbf{~ p m} \\
(\mathbf{8}-\mathbf{h} \text { moving average) }\end{array}$ & $\mathbf{N O}_{\mathbf{2}} \mu \mathbf{g} \cdot \mathbf{~ m}^{\mathbf{3}^{-\mathbf{1}}}$ (1-h average) \\
\cline { 2 - 4 } & $\mathbf{S O}_{\mathbf{2}} \mu \mathbf{g} \cdot \mathbf{m}^{\mathbf{3}^{-\mathbf{1}}}$ (24-h average) & 15 & 1,130 \\
\hline Attention & 800 & 30 & 2,260 \\
\hline Warning & 1,600 & 40 & 3,000 \\
\hline Emergency & 2,100 &
\end{tabular}

Source: Adapted from Brazil (2018).

\section{RESULTS AND DISCUSSION}

Air quality monitoring has the main objective to protect public health; thus, the monitored places must be, preferentially, those where population is exposed (FRONDIZI, 2008). 
The concentrations obtained in the control points are shown in Table 4 below. It is observed that, except for $\mathrm{CH}_{4}$, all other pollutants showed values of $0.0 \mu \mathrm{g} \cdot \mathrm{m}^{3^{-1}}$, air temperature and relative humidity showed mean values of $19.9^{\circ} \mathrm{C}$ and $68.1 \%$.

Table 4: Data obtained in the samplings in control points.

\begin{tabular}{|c|c|c|c|c|c|c|c|}
\hline \multirow{2}{*}{ Control Points } & $\mathrm{CH}_{4}$ & $\mathrm{SO}_{2}$ & $\mathrm{CO}$ & NO & $\mathrm{NO}_{2}$ & \multirow{2}{*}{$\begin{array}{l}\mathrm{T} \\
\text { (oC) }\end{array}$} & \multirow{2}{*}{$\frac{\mathrm{RH}}{\text { (\%) }}$} \\
\hline & \multicolumn{5}{|c|}{ - } & & \\
\hline P01 & $586,666.70$ & 0 & 0 & 0 & 0 & 20.0 & 68.7 \\
\hline P02 & $520,000.00$ & 0 & 0 & 0 & 0 & 19.9 & 68.1 \\
\hline P03 & $500,000.00$ & 0 & 0 & 0 & 0 & 19.9 & 67.5 \\
\hline Mean Value & $535,555.60$ & 0 & 0 & 0 & 0 & 19.9 & 68.1 \\
\hline
\end{tabular}

$\mathrm{NO}, \mathrm{SO}_{2}, \mathrm{CO}, \mathrm{NO}$ and $\mathrm{NO}_{2}$ were registered due to the absence of emitting sources in the area, an Integral Protection Conservation Unit, evidencing that it is an environment free of these pollutants. According to Barczak et al. (2012), the transportation sector is the main emitter of atmospheric pollutants, through the burning of fossil fuels. On the other hand, $\mathrm{CH}_{4}$ showed high levels, since soil moisture favors the development of bacteria that produce it from the decomposition of the organic matter available in soil and plant litter (FURTADO NETO et al., 2019).

The mean concentration of $\mathrm{CH}_{4}, 535,555.60 \mu \mathrm{g} \cdot \mathrm{m}^{3^{-1}}$ (Table 4), was higher than the mean value $\left(219,647.56 \mu \mathrm{g} \cdot \mathrm{m}^{3^{-1}}\right.$, see Table 5) obtained in the urban area of Lages. Mean air relative humidity in control points was also higher than in the urban area, with the values reaching 68.1 and $55.3 \%$ respectively (Tables 4 and 5).

Table 5: Statistical analysis of the parameters evaluated in the urban area.

\begin{tabular}{|c|c|c|c|c|c|c|}
\hline \multirow{2}{*}{ Pollutants } & $\mathrm{CH}_{4}$ & NO & $\mathrm{NO}_{2}$ & \multirow{2}{*}{\begin{tabular}{|l|}
$T$ \\
oC \\
\end{tabular}} & \multirow{2}{*}{\begin{tabular}{|l|} 
RH \\
$\%$ \\
\end{tabular}} & \multirow{2}{*}{\begin{tabular}{|l|} 
Wind \\
$\mathrm{m} / \mathrm{s}$ \\
\end{tabular}} \\
\hline & \multicolumn{3}{|c|}{ - } & & & \\
\hline Mean Value & $219,647.56$ & 664.99 & $2,066.01$ & 22.78 & 55.30 & 10.39 \\
\hline Standard Deviation & $52.097,61$ & 494.93 & $1.491,38$ & 5.20 & 16.21 & 2.87 \\
\hline CV (\%) & 23.72 & 74.43 & 72.19 & 22.81 & 29.32 & 27.67 \\
\hline Minimum & $153,333.33$ & 0.0 & 0.0 & 13.22 & 38.00 & 6.12 \\
\hline Maximum & $396,666.67$ & 2.400 & 6.850 & 30.44 & 81 & 15.48 \\
\hline
\end{tabular}

According to EPAGRI (2020), in the sampling period, the air temperature ranged from 13.2 to $30.4^{\circ} \mathrm{C}$, relative humidity showed values between 38 and $81 \%$, and wind speed varied from 6.12 to $15.48 \mathrm{~m} / \mathrm{s}$. The pollutants $\mathrm{NO}$ and $\mathrm{NO}_{2}$ showed the highest coefficients of variation: 74.43 and $72.19 \%$ respectively. The levels of these pollutants oscillated according to the vehicular traffic behavior. In the scenarios that the vehicles were started, the concentrations were higher than those registered when they were stopped. The pollutant with the highest concentration was $\mathrm{CH}_{4}$. However, a study conducted by Dlugokencky et al. (2011), demonstrates that this is the most abundant organic chemical compound in the atmosphere, that is, its presence already occurs abundantly in a natural way.

The levels of $\mathrm{CO}$ and $\mathrm{SO}_{2}$ measured in the urban area, however, were also of $0.0 \mu \mathrm{g} \cdot \mathrm{m}^{3^{-1}}$. This does not mean that these gases are absent in the atmosphere, since they are also generated from the burning of fossil fuels. It is possible that the measurements were below the limit of detection (LOD) of the equipment.

Temperature variation along the day is associated to the changes in solar radiation. After a sunny 
day, the temperature decreases at night, reaching its minimum value late in that period, close to dawn. At noon, the sun reaches its maximum height, however, the maximum temperature is registered just a few hours later due to a difference between solar and terrestrial radiation (YNOUE et al., 2017). According to Barry et al. (2013), temperature has an inversely proportional relation with air humidity, i.e., an increase in temperature leads to a reduction in air relative humidity.

There is a correlation between air relative moisture and the concentrations of $\mathrm{CH}_{4}, \mathrm{NO}$ and $\mathrm{NO}_{2}$. The dependence between the concentrations of $\mathrm{NO}$ and NO2 is negative, since when relative humidity increases, the concentrations of these pollutants tend to reduce because water vapor, represented by relative humidity, tends to dissipate atmospheric pollutants, as well as presenting an inversely proportional relation with temperature (BARRY et al., 2013).

On the other hand, the correlation between relative humidity and $\mathrm{CH}_{4}$ is positive, i.e., air relative humidity increased and the levels of $\mathrm{CH}_{4}$ increased proportionally, what is also possible to see in Figure 2. The highest mean concentration of $\mathrm{CH}_{4}\left(282,000.00 \mu \mathrm{g} \cdot \mathrm{m}^{3^{-1}}\right)$, was registered at 8:00, after reaching the minimum daily temperature; thus, it can be considered that the highest concentration of water vapor in the atmosphere was reached. The mean minimum concentration $\left(188,888.89 \mu \mathrm{g} \cdot \mathrm{m}^{3^{-1}}\right)$ was registered at 18:00. Relative humidity decreased along the day with the increase in temperature.

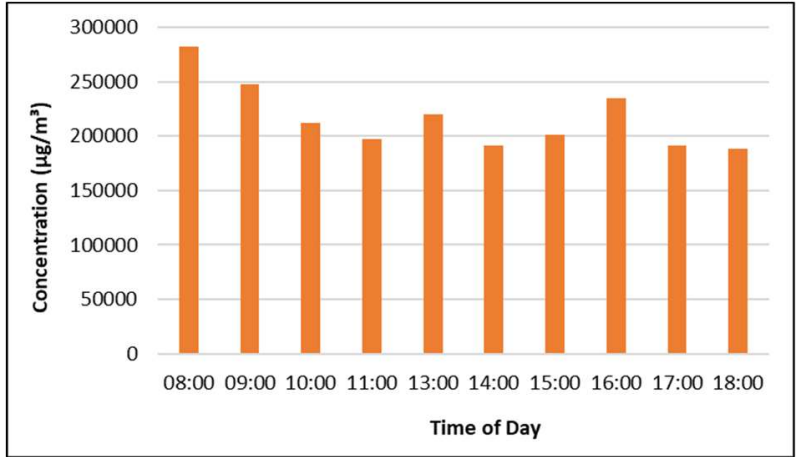

Figure 2: Hourly mean concentration of $\mathrm{CH}_{4}$.

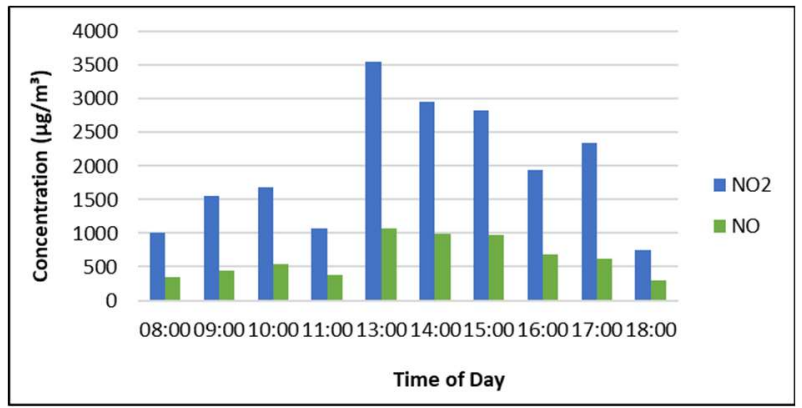

Figure 3: Hourly mean concentrations of $\mathrm{NO}_{2}$ and $\mathrm{NO}$.

Levels of $\mathrm{CH}_{4}$ associated to relative humidity, observed in the urban area may be owed to the presence of the Carahá River, located parallelly to the Belizário Ramos Avenue, which surrounds the city center. The organic matter from the Carahá River is originated from the small fraction of vegetation present in its surroundings and sewage discharge. Also, the odor coming from the gratings of the city was noticed during the samplings. These play a role of deposits of organic matter.

In the studies carried out by Xavier et al. (2019) and Ceratti et al. (2018), who conducted an atmospheric monitoring in urban areas, a positive correlation between $\mathrm{NO}$ and $\mathrm{NO}_{2}$ was found, as the concentrations of $\mathrm{NO}$ increased, the levels of $\mathrm{NO}_{2}$ also became higher.

This relation is shown in Figure 3. It is seen that the pollutants have the same behavior, except at 17:00, when $\mathrm{NO}_{2}$ showed a higher mean concentration when compared to that found at 16:00. NO had a lower hourly mean compared to the value found at 16:00. The highest hourly mean concentration for both pollutants was found at 13:00: $3,543.75 \mu \mathrm{g} \cdot \mathrm{m}^{3^{-1}}$ for $\mathrm{NO}_{2}$ and $1,075.86 \mu \mathrm{g} \cdot \mathrm{m}^{3^{-1}}$ for NO. The lowest hourly 
mean values were registered at 11:00, with $1,077.44 \mu \mathrm{g} \cdot \mathrm{m}^{3^{-1}}$ for NO2 and $375.72 \mu \mathrm{g} \cdot \mathrm{m}^{3^{-1}}$ for NO.

The presence of NO in the atmosphere has not been showing risks to human health; however, it is directly linked to the formation of $\mathrm{NO}_{2}$, since in days with higher levels of radiation, $\mathrm{NO}$ can be quickly oxidated, being transformed into $\mathrm{NO}_{2}$ (CASTRO et al., 2013). Several epidemiologic studies relate concentrations of $\mathrm{NO}_{2}$ to effects on human health, such as related by Cesaroni et al. (2013), who pointed strong evidences of mortality by exposure to $\mathrm{NO}_{2}$, mainly by cardiovascular diseases, and by Roman et al. (2015), who link the number of hospital internments due to the exposure to $\mathrm{NO}_{2}$. Figure 4 shows the behavior of the pollutants $\mathrm{CH}_{4}$ and $\mathrm{NO}_{2}$, measured along the day.

Among the measured pollutants, only $\mathrm{NO}_{2}$ has a quality standard according to the CONAMA Resolution n.491/18 and, according to Xavier et al. (2020), the legislations from the United States and European Union also do not settle quality standards for this pollutant, and can be considered similar, since they have concentration values close or even equal to the Brazilian levels.

The values used as reference in the Brazilian legislation are those determined by the World Health Organization in 2005, and correspond to the Final Standard (FS) of air quality (BRAZIL, 2018). Figure 5 shows the hourly mean concentrations of $\mathrm{NO}_{2}$ compared to the hourly and yearly mean values established by the legislation $\left(200 \mu \mathrm{g} \cdot \mathrm{m}^{3^{-1}}\right.$ and $40 \mu \mathrm{g} \cdot \mathrm{m}^{3^{-1}}$, respectively).

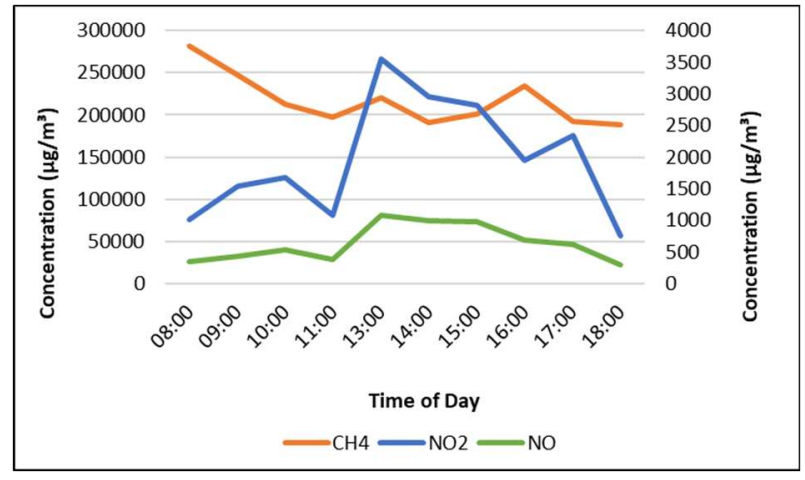

Figure 4: Comparison between the behaviors of the measured parameters.

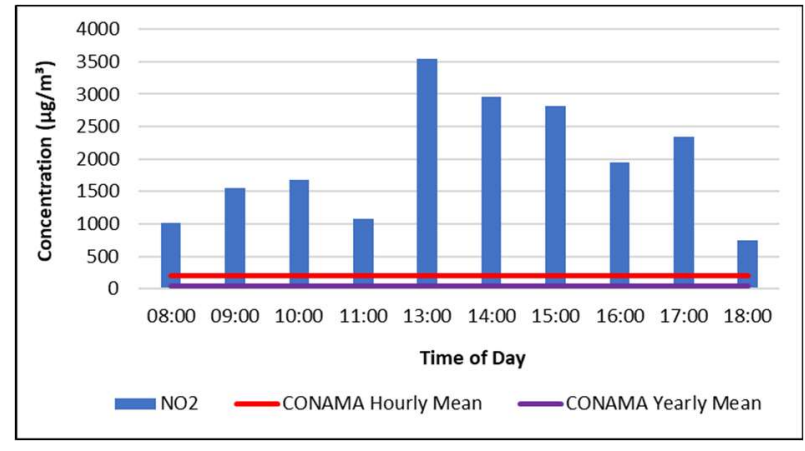

Figure 5: Hourly mean concentration of $\mathrm{NO}_{2}$ compared to the legally established value.

It can be seen in Figure 5 that the hourly means obtained in Lages are above the limits established by CONAMA. At 18:00 the lower mean value was found and, even though, this is approximately eighteen times higher than the yearly average and three times more than hourly mean established by the law. From the final mean, the air quality of the municipality can be classificated as Awful, with values between 1,130 $\mu \mathrm{g} \cdot \mathrm{m}^{3^{-1}}$ and $2,260 \mu \mathrm{g} \cdot \mathrm{m}^{3^{-1}}$, and at attention level, exceeding $1,130 \mu \mathrm{g} \cdot \mathrm{m}^{3^{-1}}$, according to the data shown in Table 6.

Table 6: Final assessment of the concentration of $\mathrm{NO}_{2}$ according to the current parameters.

\begin{tabular}{l|l|l|l|l|l}
\hline \multirow{2}{*}{ Parameter } & \multirow{2}{*}{ Mean Value Obtained } & Final Standard (2) & \multirow{2}{*}{ Air Quality Classification (3) } & \multirow{2}{*}{ Level (2) } \\
\cline { 3 - 4 } & & Hourly & Yearly & & Attention \\
\hline NO2 & $2.066,01^{(1)}$ & $200^{(1)}$ & $40^{(1)}$ & Awful & \\
\hline
\end{tabular}

(1) Concentration in $\mu \mathrm{g} \cdot \mathrm{m}^{3^{-1}}$;

(2) CONAMA Resolution n.491/18;

(3) CETESB Air Quality Index. 
Studies conducted by Souza et al. (2010), Ceratti et al. (2019), Xavier et al. (2018), and Oliveira et al. (2019), also compared the levels of $\mathrm{NO}_{2}$ to the legal standards. However, these authors used the CONAMA Resolution n.003, from June 28th 1990, as reference. This resolution was further revoked by the Resolution n.491/18. The air quality standards established by the CONAMA Resolution n.003/90 were classificated as Primary and Secondary, with the Primary being those ones that, when exceeded, may harm the health of the population; and the Secondary, standards above the limits that indicate any adverse effects to the population welfare, as well as minor harm to the flora, fauna, materials and the environment in general (BRAZIL, 1990).

The air quality instituted by the Resolution $\mathrm{n} .003 / 90$, which had $100 \mu \mathrm{g} \cdot \mathrm{m}^{3^{-1}}$ per year as primary standard and $320 \mu \mathrm{g} \cdot \mathrm{m}^{3^{-1}}$ per hour as secondary standard, was only exceeded in the study performed by Xavier et al. (2018), which was conducted utilizing a methodology similar to the used in the present study, as well as similar portable measuring equipment. The other mentioned studies showed $\mathrm{NO}_{2}$ lower than the primary and secondary standards contained in the legislation. However, these studies were performed based on different methodologies, such as Automatic Air Quality Monitoring Stations (CERATTI et al., 2019), Low Volume Air Samplers (LVS) (OLIVEIRA et al., 2019) and analysis of air quality monitoring technical reports (SOUZA et al., 2010).

\section{CONCLUSIONS}

It could be verified that the $\mathrm{NO}_{2}$ emissions in the municipality of Lages do not meet the legal standards, since the registered mean concentration of $\mathrm{NO}_{2}$ is higher than the hourly and yearly air quality Final Standard, and at Attention Level, according to the CONAMA Resolution n.491/18, still classificated as Awful according to the CETESB Air Quality Index.

Some parameters are not contained in the legislation, since the referred resolution only regards pollutants that pose danger to human health, since it follows norms established by the WHO and do not mention environmental damage. But $\mathrm{CO}_{2}$ and $\mathrm{CH}_{4}$ are extremely harmful to the environment, by being considered greenhouse effect enhancers, with NO being a precursor gas to other environmental pollutants. This gap in the legislation is not exclusive to Brazil. The United States and the European Union, which can be considered the main references in terms of politics and economy, also do not have quality standards for these pollutants.

The meteorological elements have an influence on the levels of atmospheric pollutants, increasing or decreasing their concentrations. Thus, the air quality of a given place must not be evaluated based only on the emission levels. Meteorological elements defined by the local climatic conditions must be considered as well.

\section{REFERENCES}

ABNT. Associação Brasileira de Normas Técnicas. Norma 10151: Acústica. Medição e avaliação de níveis de pressão sonora em áreas habitadas: Aplicação de uso geral. Rio de Janeiro: ABNT, 2019.
BAKONYI, S. M. C.; DANNI-OLIVEIRA, I.; M. MARTINS, L. C.; BRAGA, A. L. F.. Poluição atmosférica e doenças respiratórias em crianças na cidade de Curitiba, PR. Revista de Saúde Pública, São Paulo, v.38, n.5, p.695-700, 2004. 
BARCZAK, R.; DUARTE, F.. Impactos ambientais da mobilidade urbana: cinco categorias de medidas mitigadoras. Revista Brasileira de Gestão Urbana, v.4, n.1, p.13-32, 2012.

BARRY, R. G.; CHORLEY, R. J.. Atmosfera, Tempo e Clima. 9 ed. Porto Alegre: Brookman, 2013.

BAYAT, R.; ASHRAFI, K.; MOTAGH, M. S.; HASSANVAND, M. S.; DAROUDI, R.; FINK, G.; KÜNZLI, N.. Health impact and related cost of ambient air pollution in Tehran.

Environmental Research, v.176, 2019.

BRANCO, S. M.; MURGEL, E.. Poluição do ar. 2 ed. Curitiba: Moderna, 2010

BRAZIL. Ministério do Meio Ambiente. Compromisso pela Qualidade do Ar e Saúde Ambiental. Brasília: MMA, 2009.

BRAZIL. Resolução n. 003, de 28 de junho de 1990. Dispõe sobre os padrões de qualidade do ar, previstos no PRONAR. Brasília: DOU, 1990.

BRAZIL. Resolução n. 491, de 19 de novembro de 2018. Dispõe sobre padrões de qualidade do ar. Brasília: DOU, 2018.

BRUNT, H.; BARNES, J.; LONGHURST, G.; SCALLY, G.; HEYES, E.. Local Air Quality Management policy and practice in the UK: The case for greater Public Health integration and engagement. Environmental Science and Policy, v.58, p.5260,2016

CASTRO, A. H. S.; ARAÚJO, R. S.; SILVA, G. M. M.. Qualidade do ar-Parâmetros de controle e efeitos na saúde humana: uma breve revisão. Holos, v.5, n.29, p.107-121, 2013.

CERATTI, A. M.; ALVES, D. D.; RABELO, F. L.; OSÓRIO, D. M. M.. Relação do monitoramento atmosférico de $\mathrm{NO}_{2}, \mathrm{CO}$ e $\mathrm{O} 3$ obtidos pela estação de monitoramento automático da qualidade do ar da universidade FEEVALE/RS com variáveis meteorológicas. Revista Conhecimento, v.3, p.57-78, 2018. DOI: http://doi.org/10.25112/rco.v3i0.1607

CESARONI, G.; BADALONI, C.; GARIAZZO, C.; STAFOGGIA, M.; SOZZI, R.; DAVOLI, M.; FORASTIERE, F.. Long-Term Exposure to Urban Air Pollution and Mortality in a Cohort of More than a Million Adults in Rome. Environmental Health Perspectives, v.121, n.3, p.324-331,2013.

CETESB. Companhia Ambiental do Estado de São Paulo. Padrões de Qualidade do Ar. São Paulo: CETESB, 2019.

DLUGOKENCKY, E. J.; NISBET, E. G.; FISHER, R.; LOWRY, D. Global atmospheric methane: budget, changes and dangers. Philosophical Transactions of the Royal Society A, v.369, n.1943, p.2058-2072, 2011.

EBI, K.; MCGREGOR, G.. Climate change, tropospheric ozone and particulate matter and health impacts. Revista Ciência e Saúde Coletiva, v.14, n.6, p.2281-2293, 2009.

EPAGRI. Empresa de Pesquisa Agropecuária e Extensão Rura de Santa Catarina. Banco de dados de variáveis ambientais de Santa Catarina. Florianópolis: EPAGRI, 2020.

FELLENBERG, G.. Introdução aos problemas da poluição ambiental. São Paulo: Universidade de São Paulo, 1980

FRANCO, J. F.; GIDHAGEN, L.; MORALES, R.; BEHRENTZ, E.. Towards a better understanding of urban air quality management capabilities in Latin America. Environmental Science and Policy, v.102, p.43-53, 2019.

FREITAS, C. U.; JUNGER, W.; LEON, A. P.; GRIMALDI, R.; SILVA, M. A. F. R.; GOUVEIA, N.. Poluição do ar em cidades brasileiras: selecionando indicadores de impacto na saúde para fins de vigilância. Epidemiologia e Serviços de Saúde, Brasília, v.22, n.4, p.445-454, 2013.

FRONDIZI, C. A.. Monitoramento da Qualidade do Ar. Rio de Janeiro: E-papers, 2008.

FURTADO NETO, A. T.; MOURA, J. M. S.; SILVA, R.; OLIVEIRA JUNIOR, R. C.; GATTI, L. V.; RÖCKMANN, T.. Produção e Fluxo de Metano na Floresta Nacional do Tapajós. Revista Brasileira de Meteorologia, São José dos Campos, v.34, n.4, p.585-596, 2019. DOI: http://doi.org/10.1590/01027786344071

GRANGE, S. K.; CARSLAW, D. C.. Using meteorological normalization to detect interventions in air quality time series. Science of the Total Environment, v.653, p.578-588, 2019.

IAP. Instituto Adventista Paranaense. Secretaria do Meio Ambiente e Recursos Hídricos. Fontes de Poluição Atmosférica. Curitiba: IAP, 2020.

KOTTEK, M.; GRIESER, J.; BECK, C.; RUDOLF, B.; RUBEL, F.. World Map of the Köppen-Geiger climate classification updated. Meteorologische Zeitschrift, Berlin, v.15, n.3, p.259-263, 2006.

MARCO, A.; PROIETTI, C.; ANAV, A.; CIANCARELLA, L.; D'ELIA, I.; FARES, S.; FORNASIER, M. F.; FUSARO, L.; GUALTIERI, M.; MANES, F.; MARCHETTO, A.; MIRCEA, M.; PAOLETTI, E.; PIERSANTI, A.; ROGORA, M.; SALVATI, L.; SALVATORI, E.; SCREPANTI, S.; VIALETTO, M. V.; LEONARDI, C.. Impacts of air pollution on human and ecosystem health, and implications for the National Emission Ceiling Directive: Insights from Italy. Environment International, v.125, p.320-333, 2019.

MONTEIRO, M. A.. Caracterização climática do estado de Santa Catarina: uma abordagem dos principais sistemas atmosféricos que atuam durante o ano. Geosul, Florianópolis, v.16, n.31, p.69-78, 2001.

NASCIMENTO, C. B.; DEMETRIO, D. W.. Lages em Números. Florianópolis: SEBRAE/SC-Serviço de Apoio às Micro e Pequenas Empresas de Santa Catarina, 2017.

OLIVEIRA, M. L. M.; LOPES, M. H. P. S.; POLICARPO, N. A.; ALVES, C. M. A. C.; ARAÚJO, R. S.; CAVALCANTE, F. S. A.. Avaliação de poluentes do ar em áreas de recreação urbana na cidade de Fortaleza. Revista Brasileira de Gestão Urbana, v.11, 2019. DOI: http://doi.org/10.1590/21753369.011.e20180187

QI, X.; MEI, G.; CUOMO, S.; LIU, C.; XU, N.. Data analysis and mining of the correlations between meteorological conditions and air quality: A case study in Beijing. Internet of Things, v.14, n.100127, 2021. Dol: http://doi.org/10.1016/j.iot.2019.100127 
ROMAN, V. V. L.; CARVALHO JUNIOR, J. A.; NASCIMENTO, L. F.; CESAR, A. C. G.. Efeitos de poluentes do ar e doenças respiratórias utilizando dados estimados por modelo matemático. Revista Ambiente \& Água, Taubaté, v.10, n.4, p.825-831, 2015.

SANTA CATARINA. Secretaria do Estado de Coordenação Geral e Planejamento-SEPLAN. Atlas Escolar de Santa Catarina. Florianópolis, 1986.

SOCCOL, O. J.; CARDOSO, C. O.; MIQUELUTTI, D. J.. Análise da precipitação mensal provável para o município de Lages, SC. Revista Brasileira de Engenharia Agrícola e Ambiental, Campina Grande, v.14, n.6, p.569-574, 2010.

SOUZA, T. A. B.; PAVEI, P. T.. Avaliação da concentração dos principais poluentes atmosféricos monitorados na região sul do estado de Santa Catarina. Tecnologia e Ambiente, Criciúma, v.16, 2010

TONG, C. H. M.; YIM, S. H. L.; ROTHENBERG, D.; WANG, C.; LIN, C. Y.; CHEN, Y. D.; LAU, N. C.. Projecting the impacts of atmospheric conditions under climate change on air quality over the Pearls River Delta region. Atmospheric
Environment, v.193, p.79-87, 2018.

WOLF, T.; ESAU, I.. A proxy for air quality hazards under present and future climate conditions in Bergen, Norway. Urban Climate, v.10, n.1, p.801-814, 2014. DOI: http://dx.doi.org/10.1016/j.uclim.2014.10.006

XAVIER, J. A.; BECEGATO, V. A.; BAUM, C. A.; ROSINI, D. N.; DALALIBERA, A.; DUMINELLI, E.; HENKES, J. A.; FILHO, M. F. Avaliação da poluição do ar originada por veículos automotores na área urbana do município de Lages-SC. Revista Gestão \& Sustentabilidade Ambiental, v.8, n.1, p.149-182, 2019.

XAVIER, J. A.; BECEGATO, V. A.; ROSINI, D. N.; SIMIONI, F. J.. A consolidação de políticas públicas ambientais como uma ferramenta de controle e mitigação dos efeitos causados pela poluição atmosférica no Brasil e no Mundo. In: SILVA, H. C.. Engenharia sanitária e ambiental [recurso eletrônico]: tecnologias para a sustentabilidade 5. Ponta Grossa: Atena, 2020. p.1-14.

YNOUE, R. Y.; REBOITA, M. S.; AMBRIZZI, T.; SILVA, G. A. M.. Meteorologia: noções básicas. São Paulo: Oficina de Textos, 2017.

A CBPC - Companhia Brasileira de Produção Científica (CNPJ: 11.221.422/0001-03) detém os direitos materiais desta publicação. Os direitos referem-se à publicação do trabalho em qualquer parte do mundo, incluindo os direitos às renovações, expansões e disseminações da contribuiç̃o, bem como outros direitos subsidiários. Todos os trabalhos publicados eletronicamente poderão posteriormente ser publicados em coletâneas impressas sob coordenação da Sustenere Publishing, da Companhia Brasileira de Produção Científica e seus parceiros autorizados. Os (as) autores (as) preservam os direitos autorais, mas não têm permissão para a publicação da contribuição em outro meio, impresso ou digital, em português ou em tradução. 